https://doi.org/10.52058/2786-5274-2021-2(2)-34-45

Круглов Віталій Вікторович доктор наук з державного управління, доцент, професор кафедри менеджменту та публічного адміністрування, Харківський національний університет будівництва та архітектури, вул. Сумська, 40, м. Харків, 61002, тел.: (057) 700-02-50, e-mail: virt197@gmail.com, https://orcid.org/0000-0002-7228-8635

\title{
УДОСКОНАЛЕННЯ ПРАВОВОГО МЕХАНІЗМУ ДЕРЖАВНОГО РЕГУЛЮВАННЯ РОЗВИТКУ ДЕРЖАВНО-ПРИВАТНОГО ПАРТНЕРСТВА
}

Анотація. Стаття присвячена дослідженню підходів до удосконалення правового механізму у процесі державного регулювання розвитку державноприватного партнерства (ДПП) на основі проєктів окремих законодавчих актів та змін до діючого законодавства. Метою статті $\epsilon$ обгрунтування напрямів удосконалення правового механізму державного регулювання розвитку державно-приватного партнерства. Наукова новизна дослідження полягає у розгорнутому аналізі проблематики, пов'язаної з сучасною реалізацією державноприватного партнерства в Україні, аналізі чинних стратегічних документів та розробленні пропозицій щодо удосконалення правового механізму державного регулювання розвитку ДПП за рахунок проєктів окремих законодавчих актів та змін до діючого законодавства.

Сучасні підходи до реалізації масштабних інфраструктурних об'єктів потребують пошуку державою нових моделей реалізації соціально важливих проєктів. Використання ДПП передбачає належного правового забезпечення. Проаналізовані стратегічні документи демонструють посилення ролі ДПП як ключового інструменту при реалізації соціально-економічного розвитку України.

Особливу увагу слід приділити питанням правового врегулювання процедур конкурсного визначення приватного партнера (критерії вибору, перемовини, погодження), забезпечення управління реалізацією інфраструктурних проєктів (підготовка проєкта, прозорість і підзвітність управлінської діяльності), удосконалення інституційного середовища, поліпшення інвестиційного клімату та формування сучасних підходів щодо фінансування проектів (ринок фінансового капіталу, страховий ринок), розподілу ризиків регуляторних органів. Подальші дослідження мають бути спрямовані на аналіз можливостей правового механізму щодо вдосконалення інституційного середовища розвитку державноприватного партнерства. 
Ключові слова: держава, державне регулювання, державно-приватне партнерство, правовий механізм, проєкти.

Kruhlov Vitalii Viktorovych Doctor of Sciences in Public Administration, Associate Professor, Professor Department of Management and Public Administration, Kharkiv National University of Civil Engineering and Architecture, Sumska St., 40, Kharkiv, 61002, tel.: (057) 700-02-50, e-mail: virt197@gmail.com, https//orcid.org/ 0000-0002-7228-8635

\section{IMPROVING THE LEGAL MECHANISM OF STATE REGULATION OF THE DEVELOPMENT OF PUBLIC-PRIVATE PARTNERSHIP}

Abstract. The article is devoted to the study of approaches to improving the legal mechanism in the process of state regulation of the development of public-private partnership (PPP) on the basis of draft individual legislative acts and amendments to the current legislation. The purpose of the article is to substantiate the ways of improving the legal mechanism of state regulation of the development of public-private partnership. Scientific novelty of the research lies in a detailed analysis of the problems associated with the modern implementation of public-private partnerships in Ukraine, analysis of existing strategic documents and the development of proposals for improving the legal mechanism of state regulation of PPP development through projects of individual legislative acts and amendments to current legislation.

Modern approaches to the implementation of large-scale infrastructure facilities will require the government to search for new models for the implementation of socially important projects. The use of PPPs presupposes proper legal support. The analyzed strategic documents demonstrate the strengthening of the role of PPP as a key instrument in the implementation of the socio-economic development of Ukraine.

Particular attention should be paid to the issues of legal regulation of procedures for the competitive determination of a private partner (selection criteria, negotiations, approval), ensuring the management of the implementation of infrastructure projects (project preparation, transparency and accountability of management activities), improving the institutional environment, improving the investment climate and the formation of modern approaches to financing projects (financial capital market, insurance market), distribution of risks of regulatory authorities. Further research should be aimed at analyzing the possibilities of the legal mechanism to improve the institutional environment for the development of public-private partnerships.

Keywords: state, state regulation, public-private partnership, legal mechanism, projects

Постановка проблеми. Реалізація стратегічних національних інтересів, забезпечення соціальними послугами належної якості, рівень 
конкурентоспроможності країни базується на наявності інфраструктурних об'єктів, які формують основу функціонування держави та суспільства. Крім того, національна безпека у значній мірі базується на можливості критичної інфраструктури забезпечувати безвідмовне виконання важливих завдань та потреб. Створення сучасної інфраструктури передбачає залучення значних фінансових, управлінських та технологічних ресурсів. Зазначеними можливостями, як правило, держава в необхідній мірі не володіє.

Дослідження показують, що кожен регіон світу стикається 3 хронічним розривом у забезпеченні інфраструктури. Ця проблема особливо гостра в країнах 3 низьким та середнім рівнем доходу. Окремі розрахунки визначають, що, відповідно до прогнозів, буде залучено до інфраструктури в період 2007-2040 рр. майже 79 трлн дол. США інвестицій, а потреби в інвестиційних ресурсах за вказаний проміжок часу знаходяться на рівні 94 трлн дол. США. Моделювання показує, що, відповідно до нинішнього сценарію тенденцій світу, необхідно буде продовжувати виділяти на інфраструктурні витрати на рівні від 3,0 до 3,5 \% ВВП [1]. Оскільки більшість інвестицій в інфраструктуру здійснюється безпосередньо державним сектором, то державно-приватне партнерство (ДПП), стає засобом посилення ефективності бюджетних видатків та додатковим джерелом інвестицій. Для забезпечення стратегічного та ефективного інвестування в інфраструктуру вирішальними стає удосконалення правового механізму державного регулювання розвитку ДПП.

Аналіз останніх досліджень i публікацій. Питання удосконалення правового механізму реалізації державно-приватного партнерства є цікавим для сучасних науковців. Так, Л. Криничко, С. Петрик та Ф. Криничко пропонують удосконалення правового механізму у частині регулювання етапів реалізації проєктів державно приватного партнерства за формами та напрямами [2]. О. Гофман та Г.Будурова дослідили можливість правового забезпечення використання державної гарантії в межах здійснення проектів державноприватного партнерства [3]. А. Топал проаналізовано зміст правових гарантій щодо інвестування у сфері державно-приватного партнерства [4]. Дослідження Д. Бондаренко присвячене розгляду нормативного закріплення ДПП у сучасному законодавстві України [5]. Д. Турчаком здійснено дослідження законодавчої бази розвитку державно-приватного партнерства та його юридичної природи [6]. Проте, незважаючи на зазначені дослідження, залишається актуальним наукове завдання покращання нормативно-правого забезпечення державного регулювання розвитку державно-приватного партнерства в Україні.

Мета статті - обгрунтування напрямів удосконалення правового механізму державного регулювання розвитку державно-приватного партнерства.

Виклад основного матеріалу. Процеси реалізації проектів ДПП, що пов'язані з розвитком інфраструктури, передбачають певні етапи,які можливо оцінити: нормативну якість підготовки до ДПП, конкурсні процедури відбору приватного партнера та управління великими інфраструктурними проектами. 
Країни з високим рівнем економіки та країни з низьким економічним розвитком мають різні показники, які характеризують розвиток сфери державно-приватного партнерства. Це пов'язане, в т. ч. з розвиненою практикою реалізації проектів ДПП, розвиненим інституційним середовищем та дієвою нормативно-правовою базою щодо підготовки, конкурсних процедур та управління контрактами (рис.1).

У сфері підготовки проєктів ДПП значна частина країн світу реформувала власні законодавчі акти. Але прийняті реформи, орієнтовані на широко розповсюджену практику, ще досить рідко використовується у діяльності органів державної влади. Запровадження більшої гнучкості у розробці процесу конкурсної процедури, який відповідає конкретному проєкту ДПП, було запроваджено більшою частиною країн у процесі реформування сфери партнерства держави та приватного сектору. Але окремі процеси управління контрактами ДПП, які пов'язані 3 реалізацією проєкту ДПП, (наприклад, необхідність формування секторальних стратегій на основі ДПП), ще не вийшла на дієвий рівень.

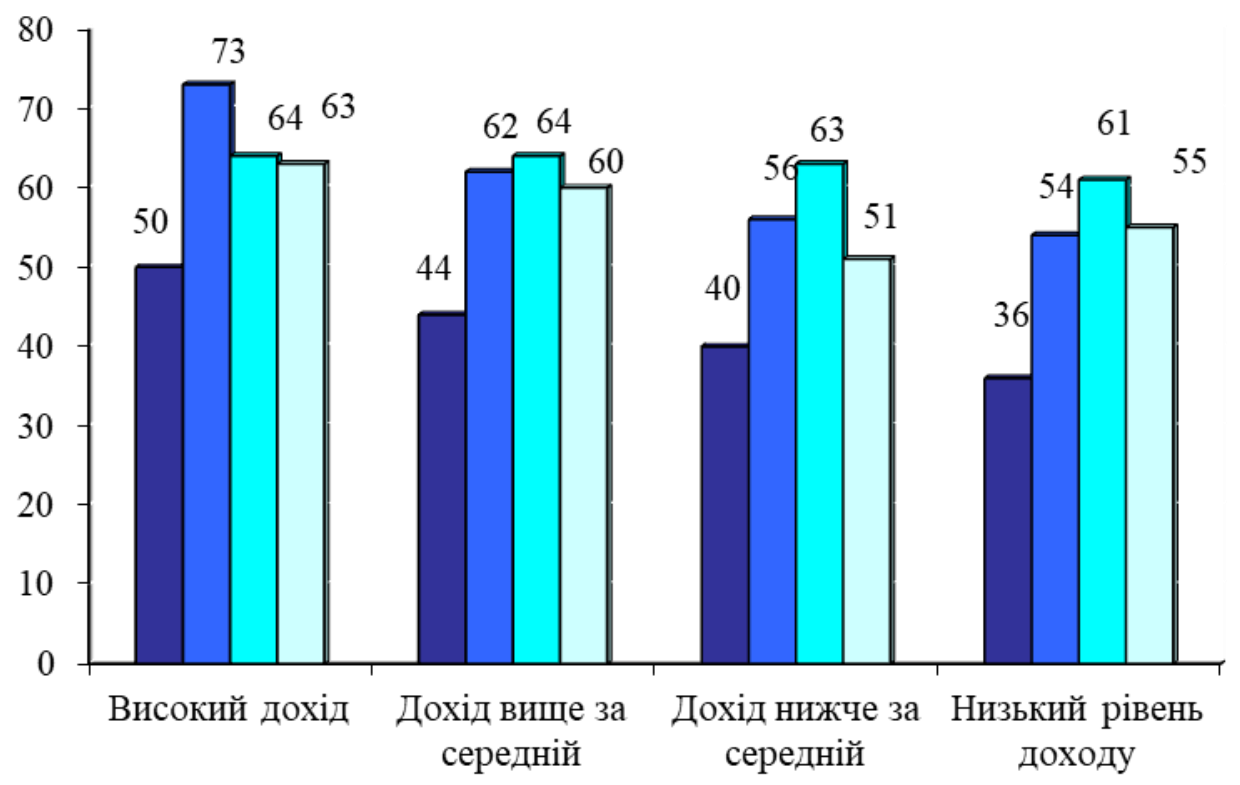

\begin{tabular}{|lll|}
\hline 口Підготовка & 口Конкурс & 口Управління \\
\hline
\end{tabular}

Puc. 1. Середні показники ДПП за групами доходів країн (оичінка 1-100, N = 140) [7]

Цілі Організації Об’єднаних Націй у галузі сталого розвитку включають інвестування в якісну інфраструктуру, що має значення для забезпечення сталого розвитку та розширення прав і можливостей громад у всьому світі. Збільшення інвестицій в інфраструктуру шляхом ДПП, заохочення ефективних партнерських відносин між державним і приватним секторами та громадянським суспільством $\epsilon$ стратегічно важливим завданням. Прозоре законодавство у сфері ДПП відіграє значну роль у розвитку ринкової економіки. Створення чіткої правової та інституційної основи є критичним фактором успіху для проєктів ДПП [7]. 
Формування політики розвитку ДПП в значній мірі залежить від управлінської спроможності держави. Державне управління розглядається як набір різноманітних процедур й інститутів, за допомогою яких реалізуються владні повноваження державних органів. Процес державного управління містить в собі дії щодо процесу формування, моніторингу та зміни урядових структур; можливості держави ефективно формувати та реалізовувати політику у відповідних сферах діяльності; формування необхідного відношення суспільства, суб'єктів владних відносин до інституцій, які регулюють соціально-економічну взаємодію між ними. Якість інституціонального середовища $\epsilon$ результатом ефективності державного управління. В зарубіжній науковій літературі ефективність виконання владних функцій в державному управлінні оприлюднюється як Всесвітні показники управління - The Worldwide Governance Indicators (WGI) щодо понад 200 країн світу. WGI визначає основні аспекти управління [8]: право голосу та підзвітність; політична стабільність і відсутність насильства; ефективність уряду; якість регулятивної діяльності; верховенство закону; рівень корупції.

У базі даних Всесвітнього Банку, які характеризують рівень державного управління в Україні з відповідними датами: 2009, 2014, 2019 рр. (рис. 2), можна визначити зміни окремих показників, що безпосередньо мають вплив і на сферу реалізації проектів державно-приватного партнерства. 3 вищенаведених даних видно, що в той час як зростає якість законодавства, забезпечується право голосу та підзвітність, достатньо проблемними залишаються високий рівень корупції та політична ситуація, пов’язана $з$ конфліктом на сході країни.

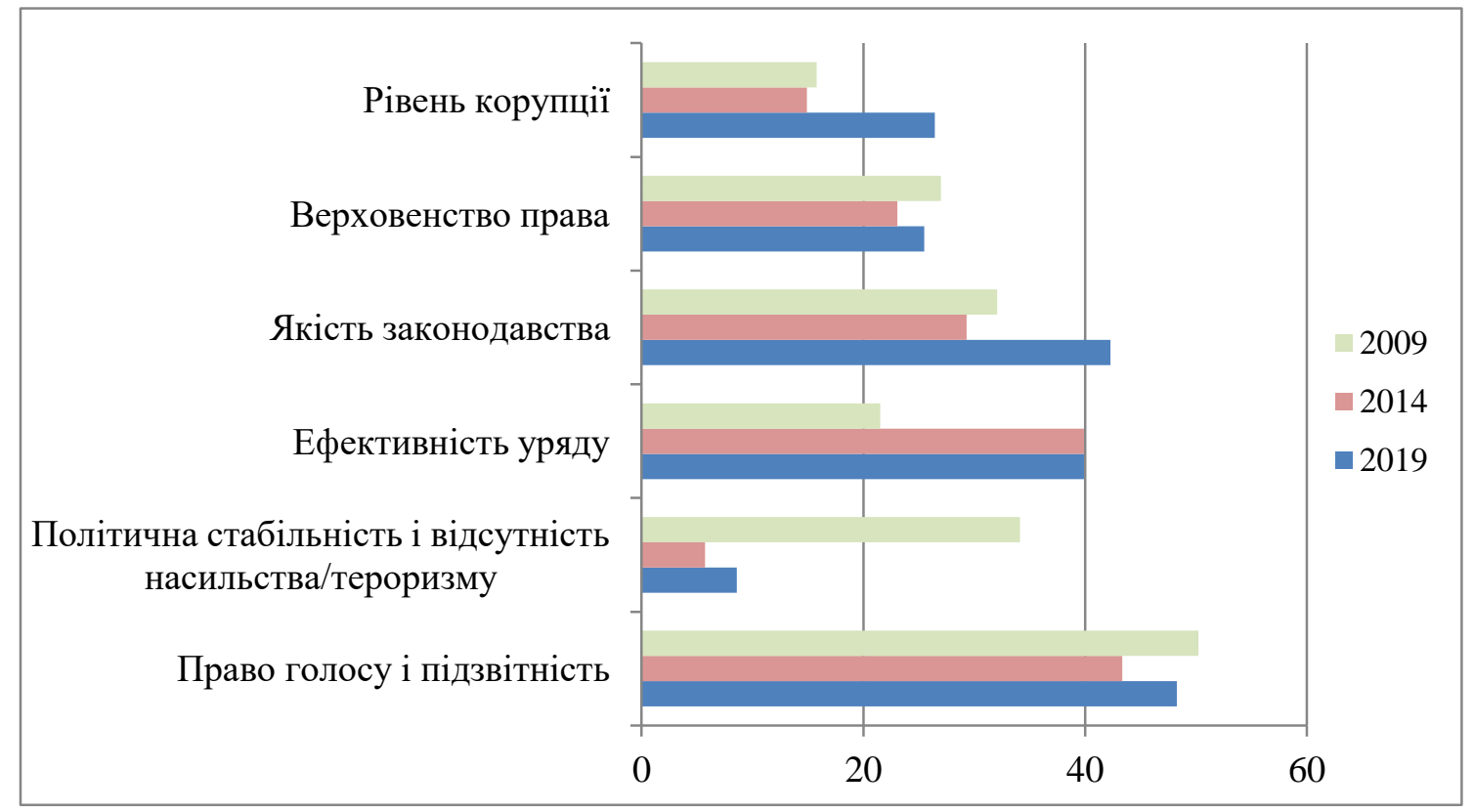

Pис. 2. Динаміка показників державного управління в Украӥні Джерело: побудовано автором на основі [8]. 
Ще однією характеристикою існуючої політики та умов розвитку ДПП в Україні слугує Індекс Infrascope, що складається з п’яти напрямів оцінювання та 23 індикаторів [9]. Відповідно до порівняння показників України у сфері реалізації ДПП 3 аналогічними середніми показниками 12 країн (Албанія, Білорусь, Єгипет, Грузія, Йорданія, Казахстан, Марокко, Румунія, Сербія, Словаччина, Туреччина) (рис. 3) бачимо, що правове регулювання; інвестиційний та бізнес-клімат; інституції; фінансування отримали показники нижчі ніж у середньому по країнах, які досліджувалися.

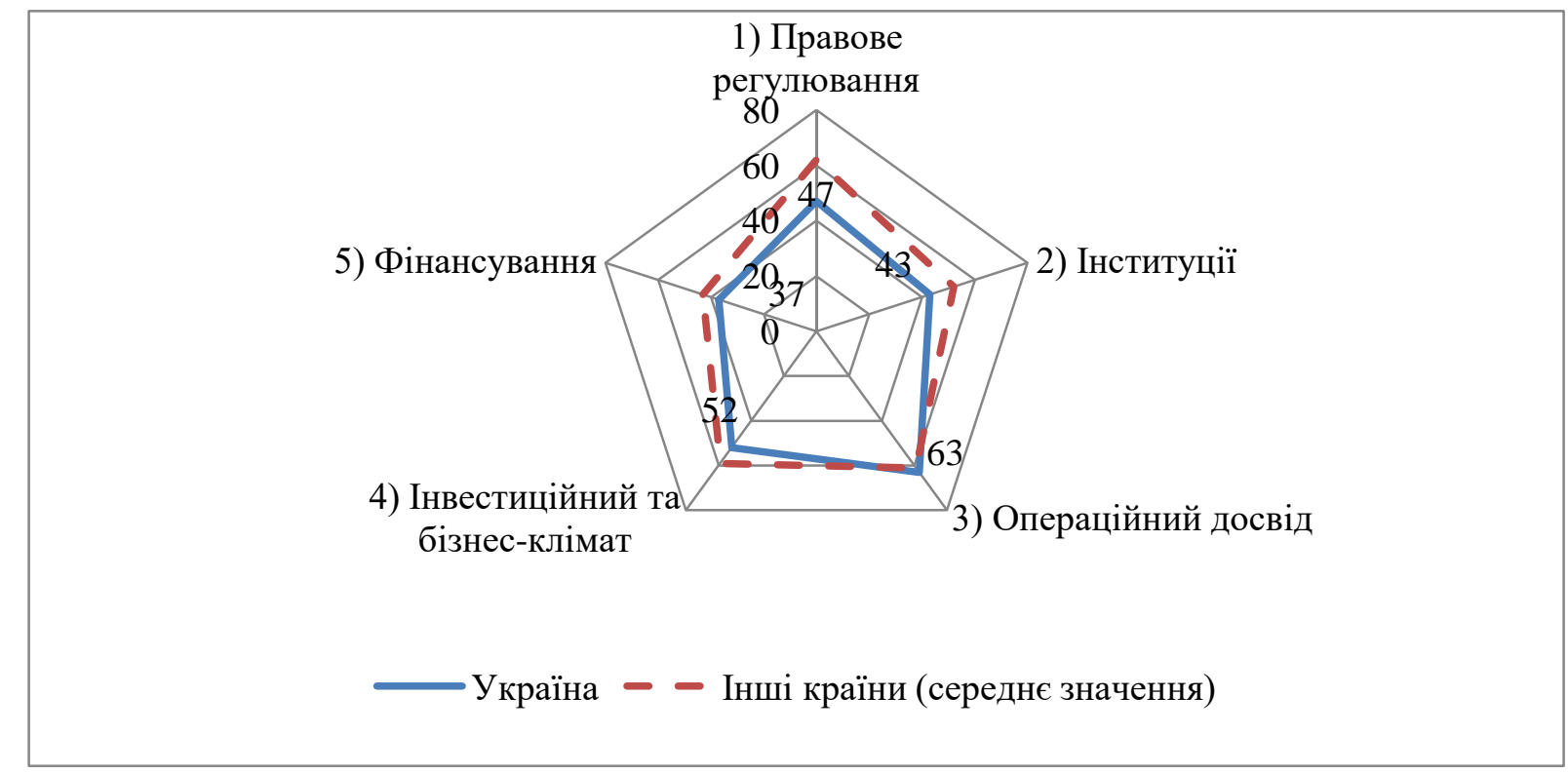

Pис. 3. Умови розвитку державно-приватного партнерства

Джерело: побудовано автором на основі [9].

Складний механізм державного регулювання поєднує у собі різні елементи: економічні, мотиваційні, організаційні, політичні та правові. Регулювання коригує роботу системи (елементів системи), маючи на меті досягнення системою (елементами системи) стану, який забезпечує іiі діяльність у відповідності 3 визначеними характеристиками. Зазначений вид діяльності розуміється як процес регуляції, з метою отримання необхідного рівня взаємодії та злагодженості окремих частин [10].

Механізм державного регулювання розвитку ДПП є сукупністю процесів (у межах системи), впливу суб'єкта (органів державної влади), на основі проактивної та реактивної дії на параметри об'єкта регулювання для стабілізуючих змін у стані об'єкта, керуючись метою та державною політикою у сфері розвитку ДПП. Організаційно-правовий механізм державного регулювання забезпечує вплив конституційно-правових норм в державі, нормативно-правового забезпечення, системи гарантування верховенства права на розвиток сфери ДПП [11].

За аналізом стратегічних документів, що існують в Україні, пов'язаних 3 
економічними напрямами, які можливо розбудовувати за рахунок механізмів ДПП, можемо дійти висновку, що затверджені стратегічні документи дозволяють окреслити певні завдання та напрями використання ДПП у розвитку відповідних сфер національної економіки (табл. 1).

Табличя 1

\section{Основні стратегічні та програмні документи, які враховують реалізацію просктів ДПП}

\begin{tabular}{|c|c|}
\hline Назва документа & Місце та роль ДПП \\
\hline $\begin{array}{l}\text { Державна стратегія } \\
\text { регіонального } \\
\text { розвитку на 2021- } \\
2027 \text { роки [12] }\end{array}$ & $\begin{array}{l}\text { Технічне переобладнання інженерної інфраструктури } \\
\text { комунального господарства. } \\
\text { Розвиток курортної інфраструктури та рекреаційних територій. } \\
\text { Розвитку сфери охорони культурної спадщини. } \\
\text { Розвиток та розширення мережі закладів освіти (дошкільних та } \\
\text { позашкільних). } \\
\text { Утворення в містах центрів розвитку креативної економіки. } \\
\text { Розбудова соціальної інфраструктури, на основі місцевих програм } \\
\text { поліпшення енергоефективності будівель. }\end{array}$ \\
\hline $\begin{array}{l}\text { План пріоритетних дій } \\
\text { Уряду на } 2021 \text { рік [13] }\end{array}$ & $\begin{array}{l}\text { Утримання та експлуатація аеропортів і інвестування в розвиток авіаційної } \\
\text { галузі }\end{array}$ \\
\hline $\begin{array}{l}\text { Національна } \\
\text { економічна } \\
\text { наратегія } \\
\text { ракеріод до } 2030 \\
\text { рок] }\end{array}$ & $\begin{array}{l}\text { Управління державною власністю. } \\
\text { Стимулювання селекціонерів щодо виведення та популяризації нових сортів } \\
\text { рослин в Україні. } \\
\text { Покращення системи дПП у сфері промисловості, що сприяє доступу до } \\
\text { енергетичної та/або транспортної інфраструктури. } \\
\text { Модернізація інфраструктури. } \\
\text { Розвиток інноваційних технологій розвідки та видобутку. } \\
\text { Будівництво підприємств з первинної переробки. } \\
\text { Впровадження кластеризації ринку. } \\
\text { Стала фінансова підтримка туристичної галузі та формування мережі } \\
\text { міжнародних представництв для промоції туристичних продуктів. } \\
\text { Реалізація програми медіаграмотності. } \\
\text { Подвоєння кількості соціальних інновацій. } \\
\text { Розвиток сфери освіти, охорони здоров’я, санаторно-курортної сфери, сфери } \\
\text { медичної науки. }\end{array}$ \\
\hline $\begin{array}{l}\text { Національна } \\
\text { транспортна } \\
\text { стратегія України на } \\
\text { період до } 2030 \text { р. [15] }\end{array}$ & $\begin{array}{l}\text { Розбудова термінальних комплексів з мультимодальними технологіями. } \\
\text { Створення міжнародних кооперацій, компаній - операторів перевезень. } \\
\text { Спрощення процедур міжнародної торгівлі. } \\
\text { Розбудова транспортної інфраструктури. } \\
\text { Розвиток авіаційної інфраструктури, реалізація стратегічних проєктів. }\end{array}$ \\
\hline $\begin{array}{l}\text { Енергетична стратегія } \\
\text { України на період до } \\
2035 \text { року [16] }\end{array}$ & $\begin{array}{l}\text { Резервування енергетичних ресурсів та їх стратегічних запасів. } \\
\text { Інвестування в паливно-енергетичному комплексі. }\end{array}$ \\
\hline
\end{tabular}

В інших проаналізованих стратегічних документах посилання на механізми ДПП мають більш декларативний характер без уточнення секторальної 
специфіки використання цього виду партнерства, що в подальшому вимагає внесення відповідних змін щодо визначення конкретних механізмів ДПП відповідно до секторальних особливостей розвитку галузі та окреслення завдань, які пов'язано із застосуванням ДПП у стратегічних документах. Вказані стратегічні документи, що виступають деталізацією загальних програм, повинні бути побудовані на основі прогнозування економічного і соціального розвитку України, і саме прогноз як стратегічний документ всеосяжного характеру потребує якнайшвидшого розроблення.

Поточна Програма дій Уряду та Державний бюджет України на поточний рік повинні враховувати Стратегію розвитку ДПП, спрямовану на вирішення завдань наповнення бюджету та вирішення поточних та стратегічних планів Уряду. Необхідним є забезпечення узгодження зі Стратегією розвитку ДПП в Україні програм соціально-економічного розвитку регіонів та аналогічних місцевих програмних документів, де передбачено використання механізмів ДПП. Таким чином, існуючі та майбутні стратегічні документи повинні забезпечувати єдину державну політику на загальнодержавному, регіональному та секторальному рівні у сфері розвитку ДПП.

Удосконалення правового механізму державного регулювання ДПП повинно передбачати зосередження, на нашу думку, на ключових напрямах системи розвитку ДПП в Україні: державне управління, економіка, регіональний розвиток, інновації. Законодавче забезпечення механізму, змістове наповнення та очікувані результати упровадження нормативно-правових актів подано в табл. 2. Вказані в таблиці підходи щодо законодавчого забезпечення функціонування правового механізму розвитку цього виду договірних партнерських відносин передбачають основний перелік розроблення та прийняття законодавчих актів для комплексного підходу щодо впорядкування функціонування системи ДПП в Україні та подальшого розвитку інституційного середовища, що дає можливість досягти встановлених цілей.

Таблиия 2

Законодавче забезпечення правового механізму державного регулювання розвитку ДПП

\begin{tabular}{|c|c|c|}
\hline $\begin{array}{l}\text { Нормативно-правове } \\
\text { забезпечення }\end{array}$ & Змістове наповнення & Очікувані результати \\
\hline 1 & 2 & 3 \\
\hline $\begin{array}{lr}\text { Прийняття } & \text { Закону } \\
\text { України } & \text { «Стратегія } \\
\text { розвитку } & \text { державно- } \\
\text { приватного партнерства в } \\
\text { Україні» }\end{array}$ & $\begin{array}{lr}\text { Визначення } & \text { мети, основних } \\
\text { завдань, } & \text { принципів, } \\
\text { суб'єктного складу реалізації } \\
\text { стратегї та індикаторів } \\
\text { упровадження стратегії }\end{array}$ & $\begin{array}{l}\text { Довгостроковий розвиток системи ДПП на основі } \\
\text { цілей, завдань та державної політики у зазначеній } \\
\text { сфері, що включає збільшення кількості проєктів } \\
\text { ДПП, залучення інвестиційний ресурсів, } \\
\text { інфраструктурну розбудову }\end{array}$ \\
\hline $\begin{array}{lr}\text { Прийняття } & \text { Постанови } \\
\text { Кабінету } & \text { Міністрів } \\
\text { України «Про } & \text { створення } \\
\text { Агентства 3 } & \text { розвитку } \\
\text { ДПП» } & \\
\end{array}$ & 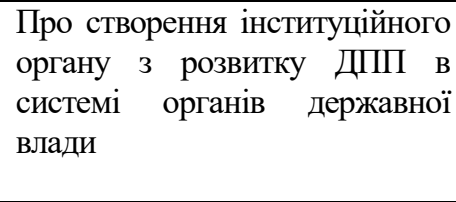 & $\begin{array}{l}\text { Комплексний підхід до розвитку партнерства } \\
\text { держави та приватного сектору, делегування } \\
\text { державою окремих повноважень приватним суб’єктам, } \\
\text { залучення інвестицій, розбудова інфраструктури, } \\
\text { забезпечення населення якісними послугами }\end{array}$ \\
\hline
\end{tabular}




\begin{tabular}{|c|c|c|}
\hline $\begin{array}{lr}\text { Прийняття } & \text { Закону } \\
\text { України } & \text { «Національна } \\
\text { стратегія } & \text { розвитку } \\
\text { кластерів» } & \end{array}$ & $\begin{array}{l}\text { Засади формування } \\
\text { пріоритетних дій держави із } \\
\text { забезпечення створення та } \\
\text { функціонування } \\
\text { промислових, інноваційних, } \\
\text { туристичних, } \\
\text { сільськогосподарських та } \\
\text { інших кластерів }\end{array}$ & $\begin{array}{l}\text { Забезпечення державної політики } \\
\text { кластерних підходів в економіці, реалізація } \\
\text { проєктів ДПП на основі кластерів }\end{array}$ \\
\hline $\begin{array}{l}\text { Прийняття змін до Закону } \\
\text { України «Про державно- } \\
\text { приватне партнерство» }\end{array}$ & $\begin{array}{l}\text { Включення ОТГ, } \\
\text { інших суб'єктів державної } \\
\text { влади до переліку суб'єктів, } \\
3 \text { якими можливо укласти } \\
\text { угоди ДПП }\end{array}$ & Розширення суб’єктного складу учасників ДПП \\
\hline $\begin{array}{lr}\text { Прийняття } & \text { Закону } \\
\text { України } & \text { «Стратегія } \\
\text { розвитку } & \\
\text { високотехнологічних } \\
\text { галузей» }\end{array}$ & $\begin{array}{l}\text { Напрями та шляхи розвитку } \\
\text { високотехнологічних } \\
\text { галузей }\end{array}$ & $\begin{array}{l}\text { Забезпечення розвитку } \\
\text { високотехнологічних } \\
\text { галузей iз використанням сучасних механізмів } \\
\text { (державна підтримка проєктів ДПП, кластерні } \\
\text { підходи) }\end{array}$ \\
\hline Прийняття & Визначення & Упорядкування єдиної системи обліку \\
\hline $\begin{array}{l}\text { Постанови Кабінету } \\
\text { Міністрів України «Про } \\
\text { порядок формування та } \\
\text { ведення } \\
\text { реєстру проєктів ДПП» }\end{array}$ & $\begin{array}{lr}\text { процедури } & \text { функціонування } \\
\text { Державного } & \text { реєстру } \\
\text { проєктів ДПП, розпорядника } \\
\text { реєстру, та } \\
\text { реєстру наповнення } \\
\text { відомостями }\end{array}$ & $\begin{array}{l}\text { проєктів ДПП та наступний моніторинг реалізації } \\
\text { проєктів ДПП }\end{array}$ \\
\hline
\end{tabular}

Впровадження зазначених підходів до вдосконалення правового механізму державного регулювання розвитку ДПП дозволить комплексно підійти до реалізації зазначеного виду партнерства 3 урахуванням використання функцій державного регулювання. Запропоновані проєкти законодавчих актів та зміни до діючого законодавства мають розширити можливості державно-приватного партнерства у інноваційні сфері, розвитку кластерного підходу в економіці, упорядкувати ведення реєстру проектів ДПП та покращити інституційне середовище реалізації інфраструктурних проєктів.

Висновки. Отже, сучасні підходи до реалізації масштабних інфраструктурних об’єктів потребують пошуку державою нових моделей реалізації соціально важливих проєктів. В якості засобу посилення ефективності бюджетних видатків та додаткового джерела інвестицій при будівництві інфраструктури досить активно використовують державно-приватне партнерство. Але використання ДПП передбачає належного правового забезпечення. Проаналізовані стратегічні документи демонструють посилення ролі ДПП як ключового інструменту при реалізації соціально-економічного розвитку України. Але зазначена робота потребує подальшого удосконалення правового механізму розвитку ДПП в Україні, що дозволить значно посилити реалізацію завдань, передбачених стратегічними документами, на основі посилення партнерства держави та приватного сектору.

Особливу увагу слід приділити питанням правового врегулювання процедур конкурсного визначення приватного партнера (критерії вибору, перемовини, погодження), забезпечення управління реалізацією інфраструктурних проєктів 
(підготовка проєкта, прозорість і підзвітність управлінської діяльності), удосконалення інституційного середовища, поліпшення інвестиційного клімату та формування сучасних підходів щодо фінансування проектів (ринок фінансового капіталу, страховий ринок), розподілу ризиків регуляторних органів. Подальші дослідження мають бути спрямовані на аналіз можливостей правового механізму щодо вдосконалення інституційного середовища розвитку державноприватного партнерства.

\section{Jimepamypa:}

1. Global Infrastructure Outlook: Infrastructure Investment Needs 50 Countries, 7 Sectors to 2040. Australia: Oxford Economics, 2017. 213 p.

2. Криничко Л. Р., Петрик С. М., Криничко Ф. Р. Удосконалення правового механізму реалізації державно-приватного партнерства як інвестиційного проєкту в сфері охорони здоров'я. Інвестиції: практика та досвід. 2020. № 23. С. 131-137.

3. Гофман О. Р., Будурова Г. М. Сучасні перспективи використання інституту державної гарантії в механізмі державно-приватного партнерства. Право і суспільство. 2019. №5. С. 107-111.

4. Топал А. До питання гарантій у разі здійснення інвестування у сфері державноприватного партнерства. Юридичний вісник. 2020. № 6. С. 234-240.

5. Бондаренко Д. С. Визначення поняття «державно-приватне партнерство» в сучасній правовій доктрині та його нормативне закріплення в законодавстві України. Юридичний науковий електронний журнал. 2014. № 1. С. 64-68.

6. Турчак Д. В. Нормативно-правове забезпечення державно-приватного партнерства в сфері охорони здоров'я. Сучасні проблеми державного управління в умовах системних змін. Серія «Державне управління». 2018. Т. ХІХ. Вип. 307. С. 137-142.

7. Benchmarking Infrastructure Development 2020 : Assessing Regulatory Quality to Prepare, Procure, and Manage PPPs and Traditional Public Investment in Infrastructure Projects. World Bank, Washington, 2020. URL: https://openknowledge.worldbank.org/handle/10986/34608.

8. Worldwide Governance Indicators. URL: http://info.worldbank.org/governance/wgi/index. aspx\#reports.

9. Measuring the enabling environment for public-private partnerships in infrastructure. The Economist Intelligence Unit. URL: https://infrascope.eiu.com/.

10. Бачинський А. Я. Механізми державного регулювання підприємницької діяльності в Україні. «Вчені записки ТНУ імені В. І. Вернадського. Серія: Державне управління». 2018. Том 29(68). № 2. С. 52-55.

11. Круглов В. В. Особливості механізмів державного регулювання розвитку державноприватного партнерства в Україні. Право та державне управління : зб. наук. пр. Класич. приват. ун-т. Запоріжжя : КПУ ; Херсон : ВД «Гельветика», 2018. № 3 (32), т. 2. С. 53-59.

12. Про затвердження Державної стратегії регіонального розвитку на 2021-2027 роки: постанова Кабінету Міністрів України від 05.08 .2020 p. № 695 . URL: https://zakon.rada.gov.ua/laws/show/695-2020-\%D0\%BF\#Text.

13. Про затвердження плану пріоритетних дій Уряду на 2021 рік: розпорядження Кабінету Міністрів України від 24.03.2021 p. № 276-p. URL: https://zakon.rada.gov.ua/laws/show/276-2021$\%$ D1\%80\#Text.

14. Про затвердження Національної економічної стратегії на період до 2030 року : постанова Кабінету Міністрів України від 03.03.2021 p. № 179. URL: https://zakon.rada.gov.ua/ laws/show/179-2021-\%D0\%BF\#n25. 
15. Про схвалення Національної транспортної стратегії України на період до 2030 року : розпорядження Кабінету Міністрів України від 30.05.2018 p. № 430-p. URL: http://zakon3.rada.gov.ua/laws/show/430-2018-\%D1\%80.

16. Про схвалення Енергетичної стратегії України на період до 2035 року «Безпека, енергоефективність, конкурентоспроможність» : розпорядження Кабінету Міністрів України від 18.08.2017 р. № 605-p. URL: https://zakon.rada.gov.ua/laws/show/605-2017-\%D1\%80\#n2.

\section{References:}

1. Oxford Economics. (2017). Global Infrastructure Outlook: Infrastructure Investment Needs 50 Countries, 7 Sectors to 2040. Australia [in English].

2. Krinichko, L., Petrik, S., \& Krynychko, F. (2020). Udoskonalennia pravovoho mekhanizmu realizatsii derzhavno-pryvatnoho partnerstva yak investytsiinoho proiektu v sferi okhorony zdorovia [Improvement of the legal mechanism of public-private partnership implementation as an investment project in the field of healthcare]. Investytsii: praktyka ta dosvid - Investment: Practice and Experience, 23, 131-137 [in Ukrainian].

3. Hofman, O. R., \& Budurova, H. M. (2019). Suchasni perspektyvy vykorystannia instytutu derzhavnoi harantii v mekhanizmi derzhavno-pryvatnoho partnerstva [Modern prospects for the use of the institution of state guarantee in the mechanism of public-private partnership]. Pravo $i$ suspilstvo Law and Society, 5, 107-111 [in Ukrainian].

4. Topal, A. (2020). Do pytannia harantii u razi zdiisnennia investuvannia u sferi derzhavnopryvatnoho partnerstva [On the issue of guarantees when investing in the field of public-private partnership]. Yurydychnyi visnyk - Law Herald, 6, 234-240 [in Ukrainian].

5. Bondarenko, D. S. (2014). Vyznachennia poniattia «derzhavno-pryvatne partnerstvo» v suchasnii pravovii doktryni i ta yoho normatyvne zakriplennia v zakonodavstvi Ukrainy [Concept definition «publicprivate partnership» in contemporary legal doctrine and its assignment to laws of Ukraine]. Yurydychnyi naukovyi elektronnyi zhurnal - Juridical scientific and electronic journal, 1, 64-68 [in Ukrainian].

6. Turchak, D. V. (2018). Normatyvno-pravove zabezpechennia derzhavno-pryvatnoho partnerstva $\mathrm{v}$ sferi okhorony zdorovia [Regulatory and legal support of public-private partnership in the field of healthcare]. Suchasni problemy derzhavnoho upravlinnia v umovakh systemnykh zmin. Seriia «Derzhavne upravlinnia»-Modern problems of public administration in the conditions of systemic changes. Public Administration Series, XIX(307), 137-142 [in Ukrainian].

7. World Bank. (2020). Benchmarking Infrastructure Development 2020 : Assessing Regulatory Quality to Prepare, Procure, and Manage PPPs and Traditional Public Investment in Infrastructure Projects. Washington. Retrieved from https://openknowledge.worldbank.org/handle/10986/34608 [in English].

8. World Bank. (2020). Worldwide Governance Indicators. Retrieved from http://info.worldbank.org/governance/wgi/index.aspx\#reports [in English].

9. The Economist Intelligence Unit (2021). Measuring the enabling environment for publicprivate partnerships in infrastructure. Retrieved from https://infrascope.eiu.com/ [in English].

10. Bachynskyi, A. Ya. (2018). Mekhanizmy derzhavnoho rehuliuvannia pidpryiemnytskoi diialnosti $\mathrm{v}$ Ukraini [The mechanisms of state regulation of entrepreneurial activity in Ukraine]. «Vcheni zapysky TNU imeni V.I. Vernadskoho. Seriia: Derzhavne upravlinnia» - «Scientific Notes of Taurida V.I. Vernadsky University», series «Public Administration», 29(68), 2, 52-55 [in Ukrainian].

11. Kruhlov, V. V. (2018). Osoblyvosti mekhanizmiv derzhavnoho rehuliuvannia rozvytku derzhavno-pryvatnoho partnerstva $\mathrm{v}$ Ukraini [Specifics of state regulation mechanisms of publicprivate partnership development in Ukraine]. Pravo ta derzhavne upravlinnia - Law and Public Administration, 3 (32), 2, 53-59 [in Ukrainian].

12. Postanova KMU «Pro zatverdzhennia Derzhavnoi stratehii rehionalnoho rozvytku na 20212027 roky»: vid 05.08.2020, № 695 [Resolution of the Cabinet of Ministers «On approval of the State 
Strategy for Regional Development for 2021-2027» from 05.08.2020, № 695]. zakon.rada.gov.ua. Retrieved from https://zakon.rada.gov.ua/laws/show/695-2020-\%D0\%BF\#Text [in Ukrainian].

13. Rozporiadzhennia KMU «Pro zatverdzhennia planu priorytetnykh dii Uriadu na 2021 rik»: vid 24.03.2021, № 276-p [Order of the Cabinet of Ministers «On approval of the plan of priority actions of the Government for 2021» from 24.03.2021, № 276-p]. zakon.rada.gov.ua. Retrieved from https://zakon.rada.gov.ua/laws/show/276-2021-\%D1\%80\#Text [in Ukrainian].

14. Postanova KMU «Pro zatverdzhennia Natsionalnoi ekonomichnoi stratehii na period do 2030 roku»: vid 03.03.2021, № 179 [Resolution of the Cabinet of Ministers «On approval of the National Economic Strategy for the period up to 2030» from 03.03.2021, № 179]. zakon.rada.gov.ua. Retrieved from https://zakon.rada.gov.ua/laws/show/179-2021-\%D0\%BF\#n25 [in Ukrainian].

15. Rozporiadzhennia KMU «Pro skhvalennia Natsionalnoi transportnoi stratehii Ukrainy na period do 2030 roku»: vid 30.05.2018, № 430-p [Order of the Cabinet of Ministers «On approval of the National Transport Strategy of Ukraine for the period up to 2030» from 30.05.2018, № 430-p]. zakon.rada.gov.ua. Retrieved from http://zakon3.rada.gov.ua/laws/show/430-2018-\%D1\%80 [in Ukrainian].

16. Rozporiadzhennia KMU «Pro skhvalennia Enerhetychnoi stratehii Ukrainy na period do 2035 roku «Bezpeka, enerhoefektyvnist, konkurentospromozhnist»: vid 18.08.2017, № 605-p [Order of the Cabinet of Ministers «On approval of the Energy Strategy of Ukraine for the period up to 2035 «Security, energy efficiency, competitiveness» from 18.08.2017, № 605-p]. zakon.rada.gov.ua. Retrieved from https://zakon.rada.gov.ua/laws/show/605-2017-\%D1\%80\#n2 [in Ukrainian]. 